\title{
Coffee Powder Antioxidant and Acrylamide Activity in Different Processing and Roasting Methods
}

\author{
A. Analianasari ${ }^{*}$, D. Berliana ${ }^{2}$, and Shintawati ${ }^{3}$ \\ ${ }^{1}$ Agroindustry Product Development Department, Politeknik Negeri Lampung, Indonesia \\ ${ }^{2}$ Food Agribusiness Department, Politeknik Negeri Lampung, Indonesia \\ ${ }^{3}$ Industrial Chemical Engineering Engineering/Department of Technology, Politeknik Negeri Lampung, \\ Indonesia \\ *Corresponding Author: analianasari@polinela.ac.id
}

\begin{abstract}
This research aimed to analyze the antioxidant activity of processed ground coffee and the levels of acrylamide in roasted ground coffee at different temperature levels. The research method is a descriptive qualitative method by calculating antioxidant activity with UV-Vis spectrophotometer and acrylamide content by HPLC. The results showed that the levels of acrylamide produced from processing with different roasting levels were still below the tolerance limit and had strong antioxidant activity at various roasting levels with different processing methods.
\end{abstract}

Keywords: Antioxidant, acrylamide, coffee powder

\section{Introduction}

Coffee is a popular drink consumed by many as a refreshing drink. Ali et al. (2018) states that drinking coffee is the choice of all consumers from around the world because drinking coffee will have an impact on the health of the drinkers. Coffee contains chemical compounds such as caffeine, chlorogenic acid, trigonelline, carbohydrates, fat, amino acid, organic acid, and aroma volatile (Farhaty \& Muchtaridi, 2014).

Polyphenols, especially chlorogenic acid (CGA), are currently in the limelight because of their health benefits. Along with its important role in coffee quality, taste, and bitterness, CGA also has several nutritional and functional properties which are mainly related to its antioxidant potential (Desai et al., 2019). The antioxidant potential of coffee beans and beverages has been extensively studied. Consumption of coffee drinks has been associated with several health benefits such as a reduced risk of chronic diseases such as cancer and diabetes as well as a reduction in oxidative damage caused by free radicals (Ballesteros et al., 2017). Affonso et al. (2016) reported that antioxidants from ground coffee beans can heal wounds on the skin.

In addition to the health benefits obtained from drinking coffee, some researchers report that drinking coffee has a negative effect, it is can cause carcinogenicity. The International Agency for Research Into Cancer (IARC) includes acrylamide compounds in the 'probably carcinogenic cancer' class of compounds (Mulato, 2019). The process of formation of acrylamide occurs in the roasting process.

Different roasts can produce different and distinctive coffee flavors. The roasting process results in the formation of polymer compounds, such as melanoidin which have strong antioxidants. The coffee processing process in this case is roasting using high temperatures ranging from $160-250^{\circ} \mathrm{C}$. Processing using high temperatures causes the chemical composition of coffee beans during roasting to change, such as carbohydrates and amino acids (Lingle, 2001). These two elements have an important role in the Maillard reaction to form the taste of coffee. Maillard's reaction in the roasting process causes the formation of acrylamide substances as a trigger for cancer. In 2013, Mojska and Gielecińska 
analyzed 42 coffee samples, including 11 instant coffees and 3 coffee substitutes (grains other than coffee) and they found that instant coffee had $100 \%$ more acrylamide $(358 \mathrm{mg} / \mathrm{kg})$ than roasted coffee. fresh, while substitute coffee has $300 \%$ more that is $818 \mathrm{mg} / \mathrm{kg}$ (Muchtaridi, 2018).

Acrylamide compounds become a serious issue as a cause of cancer, so several countries demand that coffee producing companies are required to include a warning about the dangers of cancer in coffee (Fadri et al., 2019). On the other hand, the roasting process with different methods and tools will give its results in the formation of taste, aroma, and antioxidants in coffee beans. The purpose of this study was to analyze the antioxidant activity of processed people's ground coffee and the levels of acrylamide in roasted ground coffee at different temperature levels.

\section{Method}

Antioxidant Activity Test

An antioxidant activity test using DPPH was carried out by measuring using a UVVis Spectrophotometer. The initial stage is to determine the maximum wavelength of $50 \mathrm{ppm}$ DPPH solution. Then, the comparison solution of quercetin and the sample solution was made with 5 concentration series. The results of the absorbance measurement of the sample solution and the control solution were plotted so that the $\%$ inhibition or $\%$ activity of antioxidant value was obtained and a regression curve was obtained which was used to calculate the IC 50 value. The comparison concentration of quercetin used is $5 \mathrm{ppm}, 10 \mathrm{ppm}$, 15 ppm, 20 ppm, and 25 ppm, and sample concentrations: 50 ppm, 100 ppm, 150 ppm, 200 ppm, and $250 \mathrm{ppm}$.

\section{Data Analysis}

The data obtained from the quantitative test of the antioxidant activity of the DPPH method is the percentage of DPPH radical scavenging. The amount of DPPH radical scavenging activity is calculated by the following equation:

$$
\text { Antioxidant activity }(\%)=\frac{\text { Abs Kontrol -Abs Sampel }}{\text { Abs Kontrol }} \times 100 \%
$$

IC50 was calculated by linear regression analysis between sample concentration vs. percent DPPH radical capture.

\section{Coffee Acrylamide Levels}

Determination of Acrylamide Levels in Coffee A sample of finely ground coffee powder was weighed as much as 1 gram and then dissolved in $10 \mathrm{~mL}$ of dichloromethane, shaken and centrifuged and the dregs were filtered (solution A). The pulp was extracted 2 times with $3 \mathrm{ml}$ of dichloromethane, filtered (solution B). Solution A and solution B were combined and $25 \mathrm{ml}$ of acetonitrile ad was added in a volumetric flask. The solution was injected into the HPLC column as much as 201 , then the peak area was recorded. The experiment was repeated 2 times.

\section{Results and Discussions}

\section{Antioxidant Activity}

The antioxidant content in ground coffee provides health benefits to the drinker. Antioxidants are our body's first line of defense against cell damage caused by free radicals 
and are essential for maintaining optimum health. Antioxidants can inactivate or stabilize free radicals before they attack cells. The capture of free radicals against DPPH radicals can determine the antioxidant activity of foodstuffs (coffee). This method is a quantitative method and the principle of the DPPH method is based on the ability of a test compound to capture radicals and reduce the color intensity of DPPH radicals. The color of the DPPH radical from purple to yellow as measured by a spectrophotometer at a wavelength of about $515 \mathrm{~nm}$ (Prior et al., 2005), in this study the wavelength used is $517 \mathrm{~nm}$. The $517 \mathrm{~nm}$ wavelength used is the same as the research by (Wigati et al., 2018). Antioxidant activity of ground coffee extract from respondents Rope coffee powder (R), PM Coffee (Tio), and Raosan Coffee $(\mathrm{G})$. This ground coffee is produced from premium coffee beans from a dry processing process, namely natural and honey (Figure 1 and Table 1).

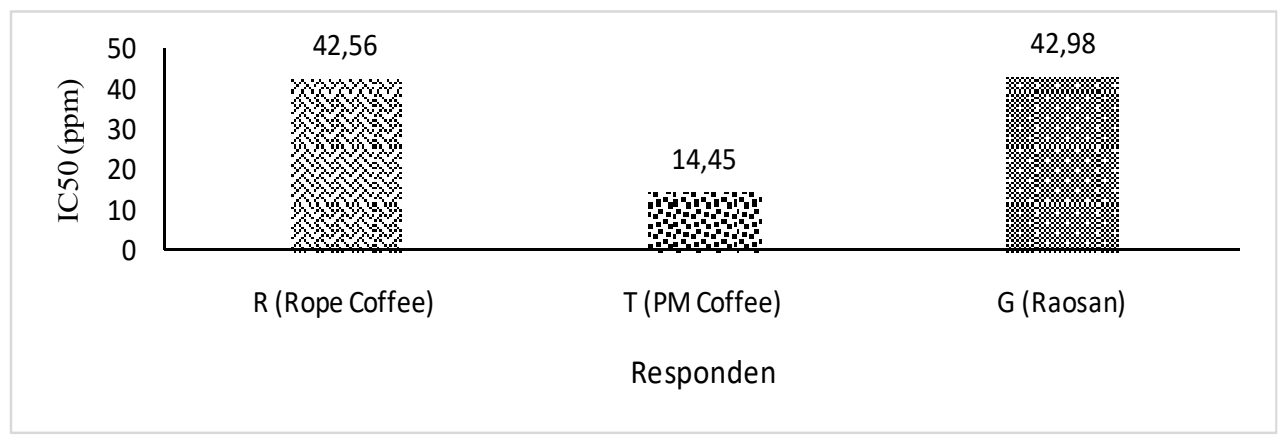

Figure 1. Antioxidant activity of IC50 (ppm) in-ground coffee three respondents

Table 1. Antioxidant activity of coffee grounds three respondents that have been produced

\begin{tabular}{clclc}
\hline No & Sample Code & IC50 ppm & Processing & Roasting Type \\
\hline 1 & R (Rope Coffee) & 42.56 & Honey & Medium \\
2 & T (PM Coffee) & 14.45 & Natural & Medium To Dark \\
3 & G (Raosan) & 42.98 & Natural & Medium To Dark \\
\hline
\end{tabular}

Table 1 and Figure 1 show that the antioxidant activity produced by the three respondents ranged from 14.45 to $42.56 \mathrm{ppm}$ from the roasting results with medium (M) (honey) and medium to dark (MD) (natural) types (Figure 2).

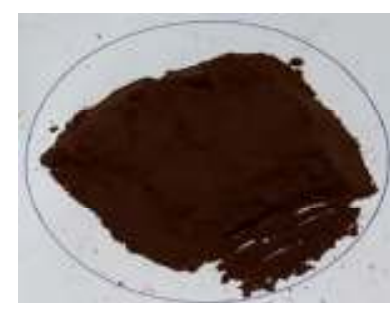

Rope Coffee (R) (M)

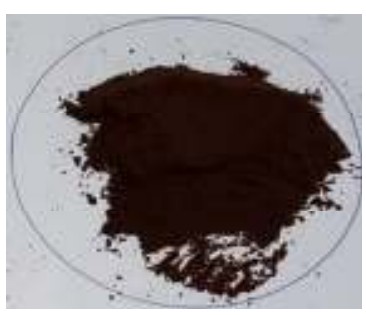

PM Coffee (T) (MD)

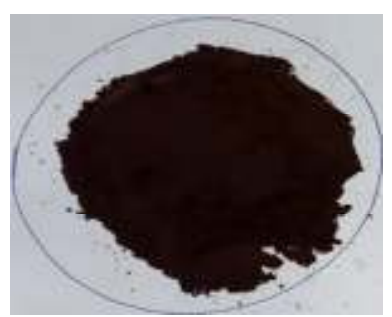

Raosan Coffee (G) (MD)

Figure 2. Types of ground coffee from three respondents with Medium and Medium to dark roasting types

Antioxidant activity in ground coffee can be seen by roasting it with a drum-type heating roasting machine with electric energy heating. Green coffee beans from three 
respondents were roasted at $165^{\circ} \mathrm{C}$ (light type) and $210{ }^{\circ} \mathrm{C}$ (medium type) (Table 2 and Figure 3).

Table 2. Antioxidant activity IC50 ppm on modern roasting machines from 3 respondents

\begin{tabular}{ccccccc}
\hline Sample & \multicolumn{6}{c}{ IC50 ppm } \\
\cline { 2 - 7 } & \multicolumn{2}{c}{ Natural } & \multicolumn{2}{c}{ Honey } & \multicolumn{2}{c}{ Full wash } \\
\hline & $\mathrm{T} 165^{\circ} \mathrm{C}$ & $\mathrm{T} 210{ }^{\circ} \mathrm{C}$ & $\mathrm{T} 165^{\circ} \mathrm{C}$ & $\mathrm{T} 210{ }^{\circ} \mathrm{C}$ & $\mathrm{T} 165^{\circ} \mathrm{C}$ & $\mathrm{T} 210{ }^{\circ} \mathrm{C}$ \\
\hline $\mathrm{R}$ & 26.07 & 82.06 & 90.6 & 50.87 & 82.06 & 49.35 \\
$\mathrm{~T}$ & 36.5 & 38.97 & 99.56 & 36.82 & 38.97 & 65.35 \\
$\mathrm{G}$ & 15.62 & 15,15 & 17.4 & 25.93 & 15,15 & 27.83 \\
\hline
\end{tabular}

The antioxidant activity of coffee extracts from ground coffee samples with different roasting temperatures of the three respondents (R, T, and $G$ ) can be seen from the IC50 values in Table 2 ranging from 15.15 to 99.56 . The IC50 value range is different for each processing method. The difference in antioxidant activity of each ground coffee extract from the difference in roasting temperature can be directly or in directly influenced by the active substances of secondary metabolites produced by plants (Wigati et al., 2018). The production of secondary metabolites in plants is influenced by several things including the climate and altitude of the planting site.

The antioxidant value of farmer respondents in the Sugarcane Garden District is due to the altitude where it grows and the formation of secondary metabolites (Utami, 2020). The smaller the IC50 value of antioxidant compounds from different processing methods (natural, honey, and full wash), the more active and the higher the place where the plant grows, the higher the antioxidant yield or said to be active.

\section{Acrylamide Level}

Acrylimide is a compound formed from the coffee roasting process from the Maillard reaction, the main pathway consisting of the reaction between asparagine and reducing sugars. Several studies have shown that acrylamide is an issue as a cancer trigger for coffee connoisseurs (Mesías \& Morales, 2016), (Muchtaridi, 2018) (Fadri et al., 2019) (Lachenmeier et al., 2019) (Nehlig \& Cunha, 2020). The formation of acrylamide is limited by the presence of a certain amount of asparagine, this causes Robusta coffee to have a higher acrylamide content because it has a higher asparagine content.

In this study, the levels of acrylamide in the coffee processing process have been carried out post-harvest well. The results of research on ground coffee from respondents who have run aground coffee industry business have acrylamide levels ranging from 5.95 to 11.2 (Table 3 and Figure 3).

Table 3. Acrylamide levels in ground coffee of respondents who have been cultivated

\begin{tabular}{cccc}
\hline \multirow{2}{*}{ No. } & Sample Code & Observation & \multirow{2}{*}{ Process } \\
\cline { 3 - 3 } & & Acrylamide (ppm) & \\
\hline 1 & R (Rope Coffee) & 9.95 & Honey \\
\hline 2 & T (PM Coffee) & 11.2 & Natural \\
\hline 3 & G (Raosan) & 5.95 & Natural \\
\hline
\end{tabular}




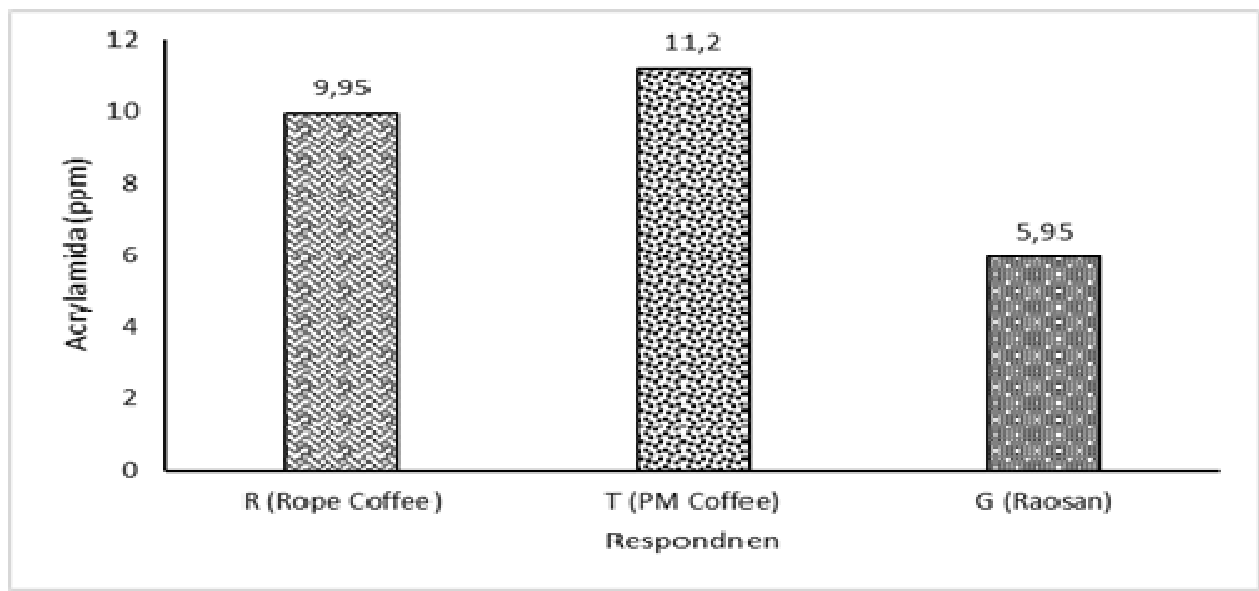

Figure 3. The level of acrylamide in ground coffee of respondents who have been cultivated

The results of the research that ground coffee from roasting with a modern rosting machine with an energy source from electricity at different temperatures and processing methods $\left(\mathrm{T} 165^{\circ} \mathrm{C}\right.$ and $\mathrm{T} 210^{\circ} \mathrm{C}$ ) has acrylamide levels ranging from 36.82 to $247.5 \mathrm{ppm}$ (Table and Figure 4).

Table 4. Acrylamide levels in ground coffee from respondents with modern roasting machines

\begin{tabular}{|c|c|c|c|c|c|c|}
\hline \multirow[t]{4}{*}{ Sample } & \multicolumn{6}{|c|}{ Observation } \\
\hline & \multicolumn{6}{|c|}{ Acrylamide (ppm) } \\
\hline & \multicolumn{2}{|c|}{ Natural } & \multicolumn{2}{|c|}{ Honey } & \multicolumn{2}{|c|}{ Full Wash } \\
\hline & Т 165 & Т 210 & T 165 & Т 210 & T 165 & T 210 \\
\hline $\mathrm{R}$ & 133.94 & 75.61 & 247.5 & 75.61 & 120.87 & 99.72 \\
\hline $\mathrm{T}$ & 205.74 & 56.75 & 115.48 & 36.82 & 188,22 & 106.99 \\
\hline $\mathrm{G}$ & 80.97 & 38.56 & 98.1 & 56.75 & 194.94 & 45.43 \\
\hline
\end{tabular}

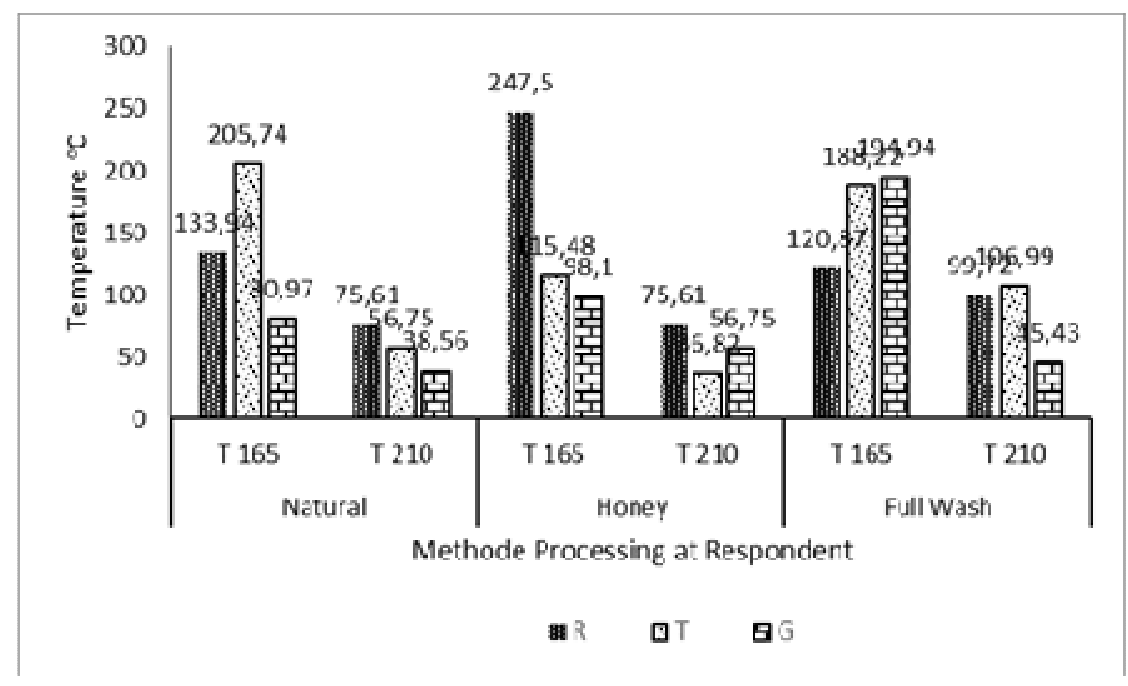

Figure 4. Acrylamide levels in ground coffee from respondents with modern roasting machines 
Respondent $\mathrm{T}$ produced the lowest acrylamide content of $36.82 \mathrm{~g} / \mathrm{kg}$ in Honey processing, while the highest was in respondent $\mathrm{R}$ with levels of $247.5 \mathrm{~g} / \mathrm{kg}$ in Honey processing. The value of acrylamide produced by the roasting process of modern rosting machines is still below the acrylamide standard tolerated by the European Commission in foodstuffs, which is 450 ppm for coffee roasting (Mesías \& Morales, 2016).

\section{Conclusions}

Based on the description, it can be concluded that the levels of acrylamide produced from processing with different roasting levels are still below the tolerance limit and have strong antioxidant activity at various roasting levels with different processing methods.

\section{Acknowledgments}

The authors would like to thank the Ministry of Education, Culture, Research and Technology, Directorate General of Higher Education, Ministry of Education, Culture, Research, and Technology, following the Multi-Year Research Contract for the Implementation of Basic Research and Development/ Capacity Number SP DIPA023.17.1.690439/2021 revision to -04 June 4, 2021.

\section{References}

Affonso, R.C.L., Voytena, A.P.L., Fanan, S., Pitz, H., Coelho, D.S., Horstmann, A.L., Pereira, A., Uarrota, V.G., Hillmann, M.C., Varela, L.A.C., Ribeiro-Do-Valle, R.M. \& Maraschin, M. (2016). Phytochemical Composition, Antioxidant Activity, and the Effect of the Aqueous Extract of Coffee (Coffea arabica L.) Bean Residual Press Cake on the Skin Wound Healing. Oxidative Medicine and Cellular Longevity, 1-10.

Ali, F., Kim, W.G., Li, J. \& Jeon, H.M. (2018). Make it delightful: Customers' experience, satisfaction, and loyalty in Malaysian theme parks. Journal of Destination Marketing and Management, 7: 1-11.

Ballesteros, L.F., Ramirez, M.J., Orrego, C.E., Teixeira, J.A. \& Mussatto, S.I. (2017). Optimization of autohydrolysis conditions to extract antioxidant phenolic compounds from spent coffee grounds. Journal of Food Engineering, 199: 1-8.

Desai, N.M., Haware, D.J., Basavaraj, K. \& Murthy, P.S. (2019). Microencapsulation of antioxidant phenolic compounds from green coffee. Preparative Biochemistry and Biotechnology, 49(4): 400-406. Tersedia di https://doi.org/10.1080/10826068. 2019.1575858.

Fadri, R.A., Sayuti, K., Nazir, N. \& Suliansyah, I. (2019). Review Proses Penyangraian Kopi Dan Terbentuknya Akrilamida Yang Berhubungan Dengan Kesehatan Review. Journal of Aplied Agricultural Science and Technology, 3(1): 129-145.

Farhaty, N. \& Muchtaridi, M. (2014). Tinjauan Kimia Dan Aspek Farmakologi Senyawa Asam Klorogenat Pada Biji Kopi : REVIEW. Farmaka, 14(1): 214-227.

Lachenmeier, D.W., Schwarz, S., Teipel, J., Hegmanns, M., Kuballa, T., Walch, S.G. \& Breitling-Utzmann, C.M. (2019). Potential Antagonistic effects of acrylamide mitigation during coffee roasting on furfuryl alcohol, furan, and 5hydroxymethylfurfural. Toxics, 7(1): 1-13.

Lingle, T. (2001). The Coffee Cupper's Handbook: A Systematic Guidw to the Sensory Evaluation of Coffee Flavor. Washington D.C: Ed. Coffee Development Group. 
Mesías, M. \& Morales, F.J. 2016. Acrylamide in coffee: Estimation of exposure from vending machines. Journal of Food Composition and Analysis, 48: 8-12.

Muchtaridi, M. (2018). Kopi Mengandung Zat Penyebab Kanker Akrilamida, Berhentikah Kita Minum Kopi? Farmasetika.com (Online), 3(1): 14.

Mulato, S. (2019). Senyawa Akrilamida Dalam Seduhan Kopi. Tersedia di https://www.cctcid.com/2019/08/26/senyawa-akrilamid-dalam-seduhan-kopi/.

Nehlig, A. \& Cunha, R.A. (2020). The coffee-acrylamide apparent paradox: An example of why the health impact of a specific compound in a complex mixture should not be evaluated in isolation. Nutrients, 12(10): 1-17.

Prior, R.L., Wu, X. \& Schaich, K. (2005). Standardized methods for the determination of antioxidant capacity and phenolics in foods and dietary supplements. Journal of Agricultural and Food Chemistry, 53(10): 4290-4302.

Utami, N.F. (2020). Potensi Antioksidan dari Biji Kpi Robusta 9 Daerah di Pulau Jawa. Journal of Chemical Information and Modeling, .

Wigati, E.I., Pratiwi, E., Nissa, T.F. \& Utami, N.F. (2018). Uji Karakteristik Fitokimia Dan Aktivitas Antioksidan Biji Kopi Robusta (Coffea Canephora Pierre) Dari Bogor, Bandung Dan Garut Dengan Metode DPPH (1,1-diphenyl-2-picrylhydrazyl). Fitofarmaka Jurnal Ilmiah Farmasi, 9(1): 1-11. Tersedia di http://dx.doi.org/10.1016/j.neuropsychologia.2015.07.010\%0A. 